\title{
Morbidity and Mortality Rates of Boer and Central Highland Goats at Ataye Crossbreeding Program Research Site: Non-parametric Survival Analysis and Piecewise Exponential Model
}

Erdachew Yitagesu Tesema ( $\nabla$ erdutella@gmail.com )

Debrebirhan Agricultural Research Center https://orcid.org/0000-0002-9695-3759

Enyiew Alemnew

Debre Birhan Agricultural Research Center

\section{Regular Articles}

Keywords: Boer, Central highland goat, Mortality, Morbidity, Survival Analysis, Survival Rate, Piecewise Exponential Model

Posted Date: February 5th, 2021

DOl: https://doi.org/10.21203/rs.3.rs-177769/v1

License: (c) (i) This work is licensed under a Creative Commons Attribution 4.0 International License.

Read Full License 


\section{Abstract}

Non-parametric survival analysis and piecewise exponential model (PEM) was used to estimate prevalence and incidence of goat mortality, to identify major clinical causes of morbidity and mortality related disease, and to investigate animal and environmental related risk factors affecting goat mortality at Ataye boer goat breeding and evaluation research site. A total of 671 kids and 347 adult (yearling) age goats were used for the analysis of non-parametric survival and piecewise exponential model for survival, mortality incidence rate and causes of morbidity and mortality analysis. The mortality incidence rate of kids and adult goats were 0.638 and 0.302 per animal year respectively. The 25th, 50th and 75 th percentile of survival time of kids were 5, 157 and 1,274 days respectively and of adult goats were 280, 828 and 1,557 days respectively. The present mortality rate is relatively larger than reports of boer cross breeding and evaluation research sites in Ethiopia as well as goat mortality prevalence abroad. Gastrointestinal related diseases, pneumonia, weak kid, agalactia, mismothering and hear water (cowdriosis) were most important causes of mortality. Constant piecewise exponential regression analysis of risk factors indicates that breed, kid birth weight (BWT), doe post-partum weight (PPWT), birth type, birth year and precipitation variables were associated with $(p$-value $<0.05)$ kid mortality rate. Pure boer kids compared with CHG cross boer goat, are 2.505 times at higher probability of mortality $(p \leq 0.001)$. A 1 kilo gram increase of kid birth weight and dam PPWT reduces mortality probability by $32.5 \%$ ( $p$-value $\leq$ $0.001)$ and $6.4 \%$ (p-value $\leq 0.001$ ) respectively. Twin birth kids are1.512 times higher rate of mortality ( $p$ value $=0.001)$ compared with single born kids. A one-millilitre increment of 15 days average precipitation significantly reduces kid mortality by $7.8 \%$ ( $p$-value $\leq 0.001$ ). Fleshing of does during early meeting to improve the post-partum weight of does and kids is also important to reduce both kid and doe mortality at and after kidding. Immunization of new introduced and kids to common endemic diseases in the area, extensive control of ticks to breakdown heart water transmission and use of proper comfortable housing to reduce stress of goats is recommended. Improving nutrition particularly during scarce grazing and

browsing feed availability is important to improving the health and reducing mortality of goats in intensively managed goat farms.

\section{Introduction}

The goat population of Ethiopia is estimated to be more than 32.74 million (CSA, 2017). In Ethiopia, there were attempts in the early 1970's to cross Saanen with Afar and Highland goat types and between 1989 and 1997 to cross Anglo-Nubian with indigenous Somali goat breeds to enhance productivity of indigenous goats. However, both of the programs were not sustainable since the effort was not supported by appropriate extension packages including health, feed and management. In addition, the cross breeds did not generate more net benefit than the local breeds (Ayalew et al., 2003; Merkel and Yami, 2008). Normally, many small ruminants (sheep and goats) cross breeding programs in tropics were not successful. This is due to the incompatibility of the genotypes with the breeding objectives, management approaches of the prevailing low input production systems of the area, absence of involvement of 
livestock owners and stakeholders in decision making and ownership of the initiatives or low regard to the potential of indigenous breed (Abraham et al., 2019).

Introduction of Boer goat breed to Ethiopia was started by inseminating Arsi-Bale goat ewes with Boer goat semen at Hawassa University and Somali ewes are also inseminated at Haramaya University to produce $\mathrm{Fl}$ crosses and the preliminary results were promising (Merkel and Yami, 2008). Boar goat as an improver to the local goats for meat production has been imported and the breeding work is going (Molla, 2016; Tesema et al., 2017; Mustefa, Gizaw, et al., 2019). Debre Birhan Agricultural Research Center, Ataye site started cross breeding and evaluation of Boer goat with Central Highland Goat (CHG) in 2011 by importing 125 Boer goats from Repeblic of South Africa and purchasing $145 \mathrm{CHG}$ ewes in two rounds. The evaluation was continued up the end of 2018. The reproductive performance of ewes, kid survival rate and mortality statistics were published from this evaluation research (Mustefa, Banerjee, et al., 2019; Mustefa, Gizaw, et al., 2019; Alemnew et al., 2020). However, there were gaps in incorporating important risk factors for kid and adult goat mortality, performing statistical assumptions and using important statistical models for survival analysis and did not include all goats and their life time period in the farm. The objective of this work is to estimate the mortality rate of kids and adult goats, identify important risk factors for mortality and summarizing important cause of goat death during the study period.

\section{Materials And Methods}

\section{Study Area and Flock Management}

The study was conducted at on-station Boer x Central Highland goat cross-breeding program of Ataye (Efratana Gidim district) Research site, Debre Birhan Agricultural Research Center, Ethiopia. In Ethiopia, three seasons exist: (i) the main rainy season (June-September, called Kiremt); (ii) the short rainy season (March-May, called Belg); and the dry season (October-February, known as Bega). Kiremt rainfall contributes largest to the annual rainfall total and covers most parts of the country except the south and southeast areas (Seleshi and Zanke, 2004). Efratana Gidim district is located in the lowland agroecological zones of central Ethiopia and the climate is characterized by bimodal rainfall consists of long rain season, called Kiremt (June-September), short rain season, called Belg (February-May) and dry season (October-January) (Fekadu, 2015; Alemayehu and Bewket, 2017). Efratana Gidim district receives annual rainfall of about $1013.6 \mathrm{~mm}$ being $65.8 \%, 20.6 \%$ and $13.6 \%$ contributed by Kiremt, Belg and Bega season respectively. The average seasonal temperature ranges from minimum of $11.3^{\circ} \mathrm{C}$ in Bega season to maximum of $31^{\circ} \mathrm{C}$ in Kiremt season (Alemayehu and Bewket, 2017). The site's geographic coordinate reference is $10^{0} 35^{\prime} \mathrm{N}$ latitude, $39^{\circ} 93^{\prime} \mathrm{E}$ longitude and $1491 \mathrm{~m}$ above sea level altitude (Fig. 1). Geographic coordinate references of Efratana Gidim district in its region and zone is display in Fig. 1.

The goat flock was a mix of different goat breed groups including Boer, Boer cross with Central Highland Goat, and Central Highland Goats. The site started cross breeding and evaluation of Boer goat with Central Highland Goat (CHG) in 2011 by importing 140 Boer goats from Repeblic of South Africa and 
managed semi-intensively with grazing and supplement. The supplement includes ad libitum grass hay, chopped pasture (Napier grass, Desmodium spp. and vetch) and commercially prepared concentrate; $300-500 \mathrm{~g} / \mathrm{head} /$ day to the adults and $100-200 \mathrm{~g} / \mathrm{head} /$ day to the kids based on their body weight. The pasture feed given to the flock depends on the forage availability across the year in the forage land. The flock health management were maintained through regular follow-up and treatment of clinical cases. Regular deworming based on carpological examination for internal parasite infestation; regular spray for external parasite and vaccination for major bacterial and viral small ruminant diseases (PPR (pestides petitis ruminantis), sheep and goat pox, ovine pasturellosis and CCPP (contagious caprine pleuropneumonia)) in the area were done. Detail summary of breeding, feeding, management system and data recording of the flock are presented in (Mustefa, Gizaw, et al., 2019).

\section{Descriptive, Non-parametric Survival Analysis and Piecewise Exponential Model (PEM)}

Data related to mortality collected during the follow-up period was entered in to an excel spreadsheet. Time the goat entered to the farm through purchase, transfer or by birth was the starting point and time of death as failure time. Daily precipitation data were taken from the near farm Majete climate data collecting sub-station. Fifteen days average precipitation were calculated and recorded for kids at their birth date. Censored observations are goats that leave out the farm by transfer or end of study period. All analyses were performed using SAS statistical software version 9.4 (SAS Institute, 2015) and STATA software version 16 (StataCorp, 2019). Estimation of the survivor function was computed as follows (Kaplan and Meier, 1958).

$$
\mathrm{S}(t)=\prod_{j: t_{j} \leq t}\left(1-\frac{d_{j}}{n_{j}}\right)
$$

Where, $\hat{S}(t)$ is the value of survival function at a time $t_{j}, n_{j}$ is the number of goats mortality free at time $t_{j}$ and $\mathrm{d}_{\mathrm{j}}$ is the number of goats died at time $\mathrm{t}_{\mathrm{j}}$. Survival curves were constructed with the Kaplan-Meier method and we used The\% NEWSURV survival curve plotting macro (Meyers, 2017).

The piecewise exponential model (PEM) is a survival model in which the time scale is divided into intervals and the hazard function is assumed constant within each interval (Allison, 2010). If there are $L$ periods, the piecewise constant transition rate is defined by $L$ parameters. The central idea of the piecewise model is that only a baseline rate, given by period-specific constants, can vary across periods, but that the covariates have the same (proportional) effects in each period. We install an STATA ado-file (stsplit) that will automatically split the episodes and estimate the piecewise constant exponential model (Cleves, 2010). Similar to the Cox proportional hazards model, PEMs model the conditional hazard function using aproportional hazard framework with a constant but different baseline hazard within a prinri dnfinnd intanuale Thn timn wanuinn affantc imanknn the proportional hazards assumption from Loading [MathJax]/jax/output/CommonHTML/fonts/TeX/fontdata.js 
"same effect over entire follow-up" to "same effect within an interval of follow-up," which should better approximate the non-proportional hazards in patient mortality after listing (Blackstone et al., 2018). We used time points at 7, 90 and 180 days to split the overall time period in to four episodes.

$$
h(t \mid x)=c_{k^{\prime}} \operatorname{xexp}\left\{X^{T} B+X^{T} B_{k}\right\}, \text { whent } \in\left(I_{k-1}, I_{k}\right)
$$

where $c_{k}$ is the baseline hazard for interval $k, I_{k}$ for $k=0, \ldots, m$ are the partition points that define each interval, $\beta$ is the overall covariate effect and is constant over time, and $\beta_{k}$ is the deviation of the covariate effect for interval $k$ from the overall effect.

\section{Results And Discussion}

\section{Descriptive Statistics and Non-Parametric Survival Analysis of Mortality and Morbidity of Goats}

The results and discussion may be presented separately, or in one combined section, and may optionally be divided into headed subsections. From 671 kids born during the follow-up period, 469 (469/671 = 70\%, 95\% Cl: 66.27-73.35\%) mortality prevalence was recorded. From 347 adult goats that was joined the farm and followed during the follow-up period, 252 (252/347 = 73\%, 95\% Cl: $67.61-77.25 \%)$ mortality prevalence was recorded. The mortality incidence rate of kids and adult goats were 0.638 and 0.302 per animal year. The 25th, 50th and 75th percentile of survival time of kids were 5, 157 and 1,274 days respectively and of adult (yearling) goats were 280, 828 and 1,557 days respectively. Incidence rate report is better than prevalence report for accurate comparison of epidemiological reports; however, incidence reports are very few in animal health studies. The present mortality rate is relatively larger than reports of boer cross breeding and evaluation research sites in Ethiopia as well as goat mortality prevalence abroad. The incidence rate is higher in new born kids than adult (yearling) age goats ( 0.638 vs 0.302$)$. Incidence rate was also higher in boer goat breeds in both age age groups. In-line with our result, $22.3 \%$ of kid loss with in the $48 \mathrm{hrs}$ age was reported in South Africa. Survival of boer goat kid is lower than Nguni goat kids (Lehloenya et al., 2005). The 25th and 50th percentile survival time of 5 and 157 days ( 5 months) in the present study is shorter than $22.2 \%, 33.8 \%$ and $42.1 \%$ of failure rate at $3,6,12$ months of kid age, and $6.73 \%$ and $16.6 \%$ mortality prevalence at pre-weaning and post-weaning age. In Jinka Agricultural Research Station, $45 \%$ of pre-weaning mortality prevalence were reported which is closer to our report (Molla, 2016). The probability of mortality failure rate for kids is rapid in the first few weeks of kid age and similarly adult goats are at higher risk of mortality in the first few months ( $\sim 9$ months) after joining the farm ( 5 days and 280 days 25 th percentile survival time of kids and adult goats respectively). A similar higher mortality of kids and lambs in their early age trend were observed. Higher mortality rate of adult goats during their early time after joining the farm might be adaptation failure of the environment and the management system of goats in the farm (Table 1). 
Table 1

Descriptive statistics and incidence rate of goat mortality $(N=1,031)$

\begin{tabular}{|lllllllll|}
\hline & & & & & & \multicolumn{5}{c|}{$\begin{array}{c}\text { Percentile survival time } \\
\text { (days) }\end{array}$} \\
\hline Age & Breed & $\begin{array}{l}\text { Time at risk } \\
\text { (animal } \\
\text { years) }\end{array}$ & IR & $\begin{array}{l}\text { All } \\
\text { goats }\end{array}$ & Died & $25 \%$ & $50 \%$ & $75 \%$ \\
\hline $\begin{array}{l}\text { Newborn } \\
\text { (kids) }\end{array}$ & Boer & 129.15 & 0.836 & 151 & 108 & 8 & 199 & 841 \\
& $\begin{array}{l}\text { CHG cross } \\
\text { Boer }\end{array}$ & 593.83 & 0.584 & 521 & 347 & 4 & 153 & 1,955 \\
& CHG & 4.65 & 1.936 & 12 & 9 & 47 & 80 & 363 \\
\hline $\begin{array}{l}\text { Adult } \\
\text { (yearling) }\end{array}$ & Sub-total & 727.63 & 0.638 & 684 & 464 & 5 & 157 & 1,274 \\
\hline & Boer & 398.39 & 0.306 & 142 & 122 & 513 & 796 & 1,653 \\
\hline CHG & 434.88 & 0.299 & 205 & 130 & 64 & 980 & 2,044 \\
\hline Total & Sub-total & 833.27 & 0.302 & 347 & 252 & 280 & 828 & 1,735 \\
\hline Note: IR - Incidence rate, CHG & - Central highland goat & & & & & \\
\hline
\end{tabular}

The distribution of causes of goat mortality and their relative contribution is presented in Table 2. During the study period, a many disease syndromes were diagnosed throgh ante-mortem and post-mortem clinical diagnosis methods. Most of the cause of death were unknown (no clear ante-mortem and/or post-mortem lesion) (44.07\%). Gastro-intestinal related (diarrea, internal-parasite and others) diseases, pneumonia, weak kid, agalactia, mismothering (also called starvation-mismothering- exposure complex), hear water (cowdriosis) and others were the most diseases syndromes diagnosed as causes of goat mortality in the farm. Gastero-intestinal related diseases (internal parasite, diarrhea ) and pneumonia are most important cause of kid mortality. (Table 2). 
Table 2

cause of goat mortality and their relative contribution

\begin{tabular}{|lllll|}
\hline Cause of death & Yearling & Adult (yearling) & Total & Relative percent \\
\hline Unknown causes & 221 & 95 & 316 & 44.07 \\
\hline GIT problems & 25 & 48 & 73 & 10.18 \\
\hline Pneumonia & 40 & 24 & 64 & 8.93 \\
\hline Miss-mothering and agalagcia & 59 & 0 & 59 & 8.23 \\
\hline Weak kid & 37 & 0 & 37 & 5.16 \\
\hline Heart water (Cowdriosis) & 19 & 15 & 34 & 4.74 \\
\hline Systemic infection & 8 & 14 & 22 & 3.07 \\
\hline Internal parasite & 15 & 6 & 21 & 2.93 \\
\hline External wound & 13 & 6 & 19 & 2.65 \\
\hline Dystocia & 4 & 12 & 16 & 2.23 \\
\hline Unthriftness & 16 & 0 & 16 & 2.23 \\
\hline Liver fluke & 2 & 12 & 14 & 1.95 \\
\hline Caseous lymphadenitis & 3 & 8 & 11 & 1.53 \\
\hline Sudden death & 2 & 10 & 12 & 1.67 \\
\hline Aging & 0 & 2 & 2 & 0.28 \\
\hline Predator & 0 & 1 & 117 & 0.14 \\
\hline Total & 464 & 253 & & 100.00 \\
\hline
\end{tabular}

During the follow-up period, most of the clinical diseases were diagnosed related to integumentary system (skin abscess, caseous lymphadenitis), respiratory system diseases (pneumonia), gasterointestinal related disorders (diarrhea) and others (Table 3). In line with our result, respiratory problem, gastero-intestinal parasite, skin local abscess were reported in recently imported boer goats breeding and evaluation research centers (Hunduma et al., 2010; Asres et al., 2014; Molla, 2016). 
Table 3

Most frequently diagnosed goat diseases category and their relative contribution in the farm

\begin{tabular}{|lll|}
\hline Disease category & Frequency & Relative percent \\
\hline Integumentary & 509 & 25 \\
\hline Respiratory & 429 & 21 \\
\hline Gastrointestinal & 333 & 16 \\
\hline Reproductive & 238 & 12 \\
\hline Nerveous & 217 & 11 \\
\hline Metabolic & 126 & 6 \\
\hline Other infectious & 124 & 6 \\
\hline Musculoskeletal & 52 & 3 \\
\hline Total disease cases & 2,028 & 100 \\
\hline
\end{tabular}

The unadjusted Kaplan - Maier survival function curve from birth to 365 days of follow-up period of kid mortality stratified based on breed of goat, season and birth type at kid birth indicates that the failure rate is steady and the overall median survival time is around 130 days (Fig. 2D). The failure rate of pure boer breed kid is lower in their early age than the CHG cross boer kids, however, the failure rate of mortality in boer goat breed is higher after around 190 days of kid age (Fig. 2A). The hazard of mortality is higher for twin birth kids as compared to single birth kids (Fig. 2B).

The unadjusted Kaplan - Maier survival function curve from entrance to the farm (at their yearling age) to 36 months of follow-up period of mortality stratified based on breed and sex of goat, year of entrance to the farm indicates that the failure rate is steady and the overall median survival time is around 27.2 months (Fig. 3D). The failure rate of CHG breed is higher than the pure boer (Fig. 3A) and goats that joined on year 2017 was at higher failure rate (Fig. 3C).

\section{Piecewise Exponential Model (PEM)}

Constant piecewise exponential regression analysis of risk factors indicates that breed, kid BWT, doe PPWT, birth type, birth year and precipitation variables were associated with ( $p$-value $<0.05)$ kid mortality rate and kid sex and doe parity number were not associated ( $p$-value $>0.05$ ) kid mortality rate. Pure boer kids compared with $\mathrm{CHG}$ cross boer goat, are 2.505 times at higher probability of mortality (p-value $\leq$ 0.001). A 1 kilo gram increase of kid birth weight and dam post-partum weight reduces mortality probability by $32.5 \%$ ( $p$-value $\leq 0.001$ ) and $6.4 \%$ ( $p$-value $\leq 0.001$ ) respectively. Twin birth kids are 1.512 times higher rate of mortality $(p$-value $=0.001)$ compared with single born kids. Kids born during the years $2012 / 132015 / 162016 / 17$ and $2017 / 18$ were at hiaher risk of mortality $(p<0.05)$ as compared with the Loading [MathJax]/jax/output/CommonHTML/fonts/TeX/fontdata.js 
base 2011/12 birth year. A one-millilitre increment of 15 days average precipitation significantly reduces kid mortality by $7.8 \%(1-0.922$, p-value $\leq 0.001)$. In this research area, natural feed resources for the goats like shrubs, trees and grass availability is highly dependent on availability of precipitation. Thus, kid mortality will reduced when the area gets higher precipitation. Mortality variation across year is due to the fluctuation of flock management, climatic variables, disease incidence and parasite infestation across the year. Kids born during the long rainy season were also at higher risk of mortality ( $P$-value $=0.008)$ as compared with the dry season. The better survival rate of kids born in the dry season contradicts with other season effect on lamb survival in Ethiopia. Kids born at the dry season in this lowland rift valley area may be due to better access of natural feed sources like grass, shrubs and tree plants in this season. In contrast to our study, season has no significant effect on dorper cross local lambs (Tesema et al., 2020), lambs born during dry season are at higher risk than other seasons (Getachew et al., 2015). This is most probably due to breed and climate zone difference of studies. Kids in their first week of age were the most at risk and risk of mortality is lowest in their 180-2431 days of age period which agreed most studies (Table 4). Kid birth weight, goat breed, birth type and year are important risk factors for kid survival rate. 
Table 4

Piecewise exponential model analysis results of explanatory variables effect on kid mortality

\begin{tabular}{|c|c|c|c|c|c|}
\hline \multirow{2}{*}{$\begin{array}{l}\text { Risk factors } \\
\text { Breed }\end{array}$} & \multirow[b]{2}{*}{ CHG cross Boer } & \multirow{2}{*}{$\begin{array}{l}\text { HR } \\
1\end{array}$} & \multicolumn{2}{|c|}{$\mathrm{HR} 95 \% \mathrm{Cl}$} & \multirow[t]{2}{*}{ p-value } \\
\hline & & & & & \\
\hline & Pure boer & 2.505 & 1.707 & 3.675 & $\leq 0.001$ \\
\hline \multirow[t]{2}{*}{ Sex } & Female & 1 (base) & & & \\
\hline & Male & 1.184 & 0.977 & 1.435 & 0.086 \\
\hline Kid BWT & & 0.675 & 0.571 & 0.797 & $\leq 0.001$ \\
\hline Doe PPWT & & 0.956 & 0.936 & 0.976 & $\leq 0.001$ \\
\hline \multirow[t]{6}{*}{ Parity } & $1 \mathrm{st}$ & 1.074 & 0.753 & 1.533 & 0.693 \\
\hline & $2 n d$ & 1.02 & 0.718 & 1.449 & 0.913 \\
\hline & $3 r d$ & 1.265 & 0.877 & 1.826 & 0.209 \\
\hline & 4 th & 1 (base) & & & \\
\hline & 5th & 1.203 & 0.778 & 1.859 & 0.407 \\
\hline & 6th & 0.961 & 0.467 & 1.976 & 0.913 \\
\hline \multirow[t]{2}{*}{ Birth type } & Single & 1 (base) & & & \\
\hline & Twin & 1.512 & 1.192 & 1.917 & 0.001 \\
\hline \multirow[t]{8}{*}{ Birth year } & $2011 / 12$ & 1 (base) & & & \\
\hline & $2012 / 13$ & 2.541 & 1.512 & 4.269 & $\leq 0.001$ \\
\hline & $2013 / 14$ & 1.511 & 0.955 & 2.392 & 0.078 \\
\hline & $2014 / 15$ & 1.371 & 0.865 & 2.174 & 0.179 \\
\hline & $2015 / 16$ & 2.209 & 1.371 & 3.558 & 0.001 \\
\hline & $2016 / 17$ & 2.868 & 1.7 & 4.838 & $\leq 0.001$ \\
\hline & 2017/18 & 4.124 & 2.398 & 7.093 & $\leq 0.001$ \\
\hline & $2018 / 19$ & 1.284 & 0.658 & 2.502 & 0.463 \\
\hline \multirow[t]{3}{*}{ Kidding season } & Dry & 1 (base) & & & \\
\hline & Short rain & 1.288 & 0.973 & 1.705 & 0.077 \\
\hline & Long rain & 1.863 & 1.172 & 2.962 & 0.008 \\
\hline
\end{tabular}




\begin{tabular}{|llllll|}
\hline Risk factors & & HR & HR 95\% Cl & p-value \\
\hline Precipitation & & 0.922 & 0.882 & 0.964 & $\leq 0.001$ \\
\hline Time interval (days) & $0-7$ & 68.717 & 54 & 87.444 & $\leq 0.001$ \\
& $7-90$ & 5.485 & 4.201 & 7.161 & $\leq 0.001$ \\
& $90-180$ & 2.162 & 1.491 & 3.136 & $\leq 0.001$ \\
& $180-2431$ & 1 (base) & & & \\
\hline
\end{tabular}

Constant piecewise exponential regression analysis of risk factors indicates that breed, kid BWT, doe PPWT, birth type, birth year and precipitation variables were associated with ( $\mathrm{p}$-value $<0.05)$ kid mortality rate and kid sex and doe parity number were not associated ( $p$-value $>0.05$ ) kid mortality rate. Pure boer kids compared with $\mathrm{CHG}$ cross boer goat, are 2.505 times at higher probability of mortality (p-value $\leq$ 0.001). A 1 kilo gram increase of kid birth weight and dam post-partum weight reduces mortality probability by $32.5 \%$ ( $p$-value $\leq 0.001)$ and $6.4 \%$ ( $p$-value $\leq 0.001)$ respectively. Twin birth kids are 1.512 times higher rate of mortality ( $p$-value $=0.001)$ compared with single born kids. Kids born during the years $2012 / 13,2015 / 16,2016 / 17$ and $2017 / 18$ were at higher risk of mortality $(p<0.05)$ as compared with the base 2011/12 birth year. A one-millilitre increment of 15 days average precipitation significantly reduces kid mortality by $7.8 \%(1-0.922$, p-value $\leq 0.001)$. In this research area, natural feed resources for the goats like shrubs, trees and grass availability is highly dependent on availability of precipitation. Thus, kid mortality will reduced when the area gets higher precipitation. Mortality variation across year is due to the fluctuation of flock management, climatic variables, disease incidence and parasite infestation across the year. Kids born during the long rainy season were also at higher risk of mortality ( $P$-value $=0.008$ ) as compared with the dry season. The better survival rate of kids born in the dry season contradicts with other season effect on lamb survival in Ethiopia. Kids born at the dry season in this lowland rift valley area may be due to better access of natural feed sources like grass, shrubs and tree plants in this season. In contrast to our study, season has no significant effect on dorper cross local lambs (Tesema et al., 2020), lambs born during dry season are at higher risk than other seasons (Getachew et al., 2015). This is most probably due to breed and climate zone difference of studies. Kids in their first week of age were the most at risk and risk of mortality is lowest in their 180-2431 days of age period which agreed most studies (Table 4). Kid birth weight, goat breed, birth type and year are important risk factors for kid survival rate. 
Table 5

Constant piecewise exponential proportional hazard regression

analysis results of explanatory variables effect on adult goat

mortality

\begin{tabular}{|lllll|}
\hline Variables & Class & HR & $95 \%$ Cl & P-value \\
\hline Breed & CHG & Base & & \\
\hline Sex & Boer & 1.503 & $1.067-2.118$ & 0.02 \\
\hline Male & 1 & & \\
\hline Year & Female & 1.434 & $0.84-2.449$ & 0.186 \\
\hline & 2011 & 1 & & \\
\hline Time interval & $0-6$ & 1.352 & $0.982-1.861$ & 0.065 \\
\hline & 2013 & 1.307 & $0.877-1.946$ & 0.188 \\
\hline & $6-9$ & 0.219 & $0.089-0.541$ & 0.001 \\
\hline & $9-18$ & 0.518 & $0.346-0.775$ & 0.001 \\
\hline & $18-24$ & 1.29 & $0.88-1.889$ & 0.192 \\
\hline & $24-$ & 1 & & \\
\hline
\end{tabular}

\section{Conclusions}

Kid and adult goat mortality rates in the present study at Ataye research site were higher than other reports in Ethiopia and abroad. Mortality rates are influenced by both animal and environmental related factors that is in line with previous studies. Management practices aimed at improving the health and survival of goats need to focus on countering the unfavourable factors. Doe giving birth during the long rain season and low precipitation, kids in their first week of age, light, and twin kids and kids born from light does should get special attention. Similarly, new introduced goats to new farms needs adequate care until they adapt the new environment. Fleshing of does during early meeting to improve the postpartum weight of does and kids is also important to reduce both kid and doe mortality at and after kidding. Immunization of new introduced and kids to common endemic diseases in the area, extensive control of ticks to breakdown heart water transmission and use of proper comfortable housing to reduce stress of goats is recommended. Improving nutrition particularly during scarce grazing and browsing feed availability is important to improving the health and reducing mortality of goats in intensively managed goat farms.

\section{Declarations}




\section{Funding}

This study was supported by Amhara Regional Agricultural Research Center (Ls/ Ah /Sh13/DB-2015/18)

\section{Author information}

\section{Affiliations}

Debre Birhan Agricultural Research Center

Erdachew Yitagesu and Enyiew Alemnew

\section{Contributions}

Both authors contributed to the study conception and design. Material preparation and data collection were performed by Erdachew Yitagesu and Enyiew Alemnew. Data analysis and writing the first draft of the manuscript was performed by Erdachew Yitagesu and both authors read and approved the final manuscript.

\section{Corresponding author}

Correspondence to Erdachew Yitagesu.

\section{Ethics declarations}

\section{Conflicts of interest}

The authors declare that they have no conflicts of interest.

\section{Ethics approval}

The Amhara Agricultural Research Institute, Bahir Dar, Research Review Team approved this research. All efforts were made to fulfil animals' welfare \& rights during the study period.

\section{Consent to participate}

Not applicable. 


\section{Consent for publication}

Not applicable.

\section{References}

1. Abraham, H., Gizaw, S. and Urge, M., 2019. Simulated alternative breeding schemes for optimizing Begait goat improvement programs in Western Tigray, northern Ethiopia Agricultural Systems, 176, 102669

2. Alemayehu, A. and Bewket, W., 2017. Local spatiotemporal variability and trends in rainfall and temperature in the central highlands of Ethiopia Geografiska Annaler: Series A, Physical Geography, $99,85-101$

3. Alemnew, E., Yitagesu, E., Goshme, S. and Aydefruhim, D., 2020. Retrospective study on kid mortality and associated risk factors of kid survival of newly introduced Boer goat breed in North Shewa Ethiopia Development, 32, 7

4. Allison, P.D., 2010. Survival analysis using SAS: a practical guide, 2. ed (SAS Press: Cary, NC)

5. Asres, Z., Nigus, B., Abiy, S., Mesfine, L. and Abebe, T., 2014. On-Station Retrospective Epidemiologic Study of Small Ruminant Disease in Sirinka Agricultural Research Center, Sheep and Goat Breeding, Evaluation and Distribution Site Academic Journal of Animal Diseases, 3, 39-44

6. Ayalew, W., Rischkowsky, B., King, J.M. and Bruns, E., 2003. Crossbreds did not generate more net benefits than indigenous goats in Ethiopian smallholdings Agricultural Systems, 76, 1137-1156

7. Blackstone, E.H., Rajeswaran, J., Cruz, V.B., Hsich, E.M., Koprivanac, M., Smedira, N.G., Hoercher, K.J., Thuita, L. and Starling, R.C., 2018. Continuously Updated Estimation of Heart Transplant Waitlist Mortality Journal of the American College of Cardiology, 72, 650-659

8. Cleves, M.A., 2010. An introduction to survival analysis using Stata, 3rd ed (Stata Press: College Station, Tex)

9. CSA, 2017. Agricultural Sample Survey Report on Livestock and Livestock Characteristics. Volume II, 2017/18., (Central Statistical Agency (CSA), Federal Democratic Republic of Ethiopia.: Addis Ababa, Ethiopia)

10. Fekadu, K., 2015. Ethiopian seasonal rainfall variability and prediction using canonical correlation analysis (CCA) Earth Sciences, 4, 112 (Science Publishing Group)

11. Getachew, T., Gizaw, S., Wurzinger, M., Haile, A. and Rischkowsky, B., 2015. Survival analysis of genetic and non-genetic factors influencing ewe longevity and lamb survival of Ethiopian sheep breeds Livest. Sci., 1-11 (Elsevier)

12. Hunduma, D., Worku, T., Moti, W. and Feyesa, R., 2010. Preliminary Study on Major Health Problems of the Newly Introduced Boer Goat Breed in Ethiopia 5

13. Kaplan, E.L. and Meier, P., 1958. Nonparametric estimation from incomplete observations Journal of the American statistical association. 53.457-481 (Taylor \& Francis)

Loading [MathJax]/jax/output/CommonHTML/fonts/TeX/fontdata.js

Page $14 / 18$ 
14. Lehloenya, K.C., Greyling, J.P.C. and Schwalbach, L.M.J., 2005. Reproductive performance of South African indigenous goats following oestrous synchronisation and AI Small Ruminant Research, 57, $115-120$

15. Merkel, R. and Yami, A., 2008. Sheep and Goat Production Handbook for Ethiopia,

16. Meyers, J., 2017. The\% NEWSURV family of macros: an update on the survival plotting macro\% NEWSURV and an introduction to expansion macros Pharma SUG, 14-17

17. Molla, B., 2016. The health performance of imported Boer goat (Capra hircus) and their crosses with Woito-guji goat breeds in South Omo Zone, South-Western Ethiopia Tropical Animal Health and Production, 48, 855-861

18. Mustefa, A., Banerjee, S., Gizaw, S., Taye, M., Areaya, A., Abebe, A. and Besufekad, S., 2019.

Reproduction and survival analysis of Boer and their crosses with Central Highland goats in Ethiopia Livestock Research for Rural Development, 31, 17

19. Mustefa, A., Gizaw, S., Banerjee, S., Abebe, A., Taye, M., Areaya, A. and Besufekad, S., 2019. Growth performance of Boer goats and their F1 and F2 crosses and backcrosses with Central Highland goats in Ethiopia Livestock Research for Rural Development, 31

20. Pellerin, A.N. and Browning, R., 2012. Comparison of Boer, Kiko, and Spanish meat goat does for stayability and cumulative reproductive output in the humid subtropical southeastern United States BMC Veterinary Research, 8, 136

21. SAS Institute, 2015. Base SAS 9.4 procedures guide, (SAS Institute)

22. Seleshi, Y. and Zanke, U., 2004. Recent changes in rainfall and rainy days in Ethiopia International Journal of Climatology, 24, 973-983

23. StataCorp, L.P., 2019. Stata data analysis and statistical Software, (StataCorp LLC)

24. Tesema, Z., Deribe, B., Kefale, A., Lakew, M., Tilahun, M., Shibesh, M., Belayneh, N., Zegeye, A., Worku, G. and Yizengaw, L., 2020. Survival analysis and reproductive performance of Dorper x Tumele sheep Heliyon, 6, e03840

25. Tesema, Z., Tilahun, M., Deribe, B., Lakew, M., Belayneh, N., Zegeye, A. and Aychew, D., 2017. Effect of non-genetic factors on pre-weaning growth, survivability and prolificacy of Central Highland $\mathrm{x}$ Boer crossbred goats in North Eastern Ethiopia Livest. Res. Rural Dev., 29, 1-11

\section{Figures}




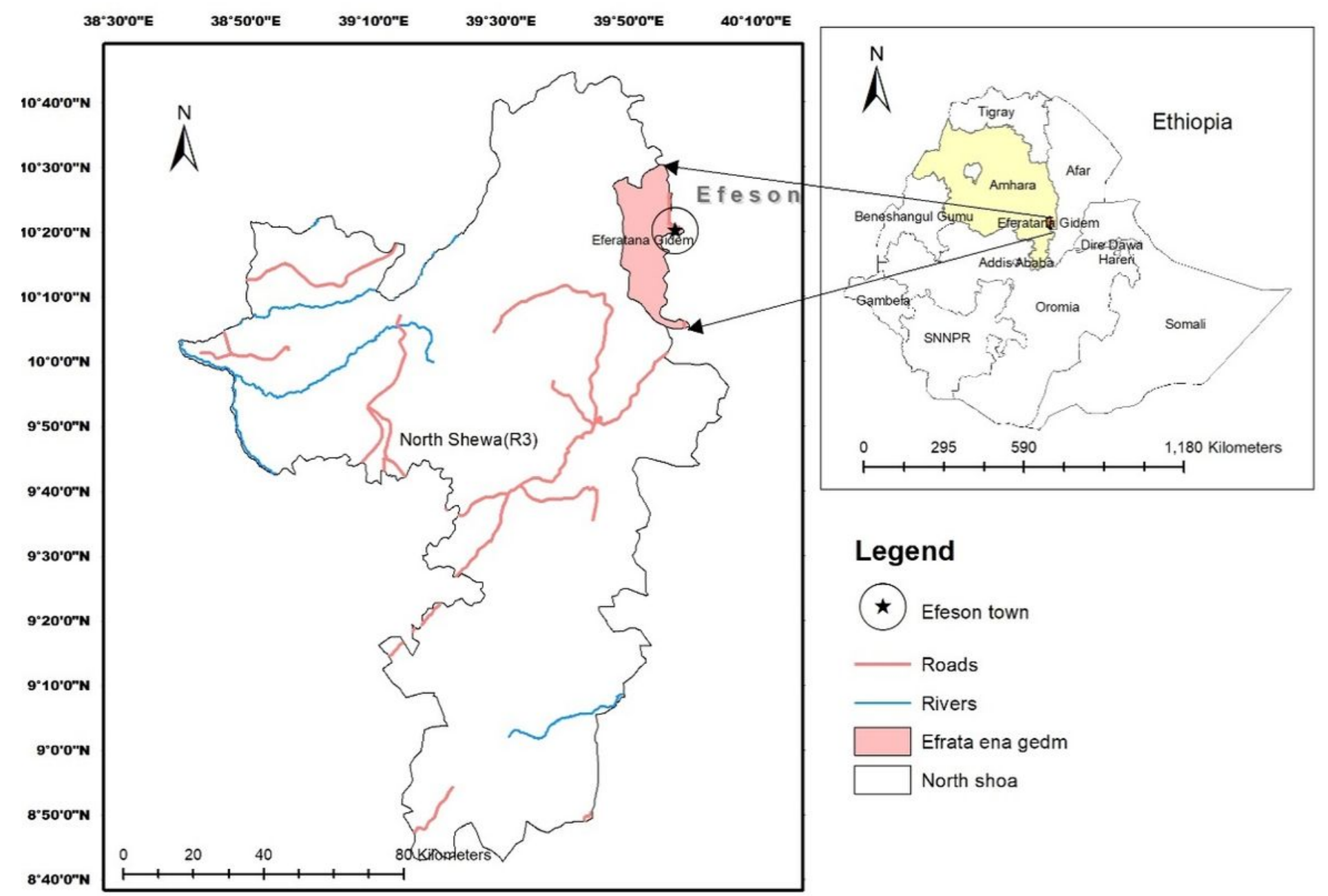

Figure 1

Geographic coordinate references of Efratana Gidim district in its region and zone 

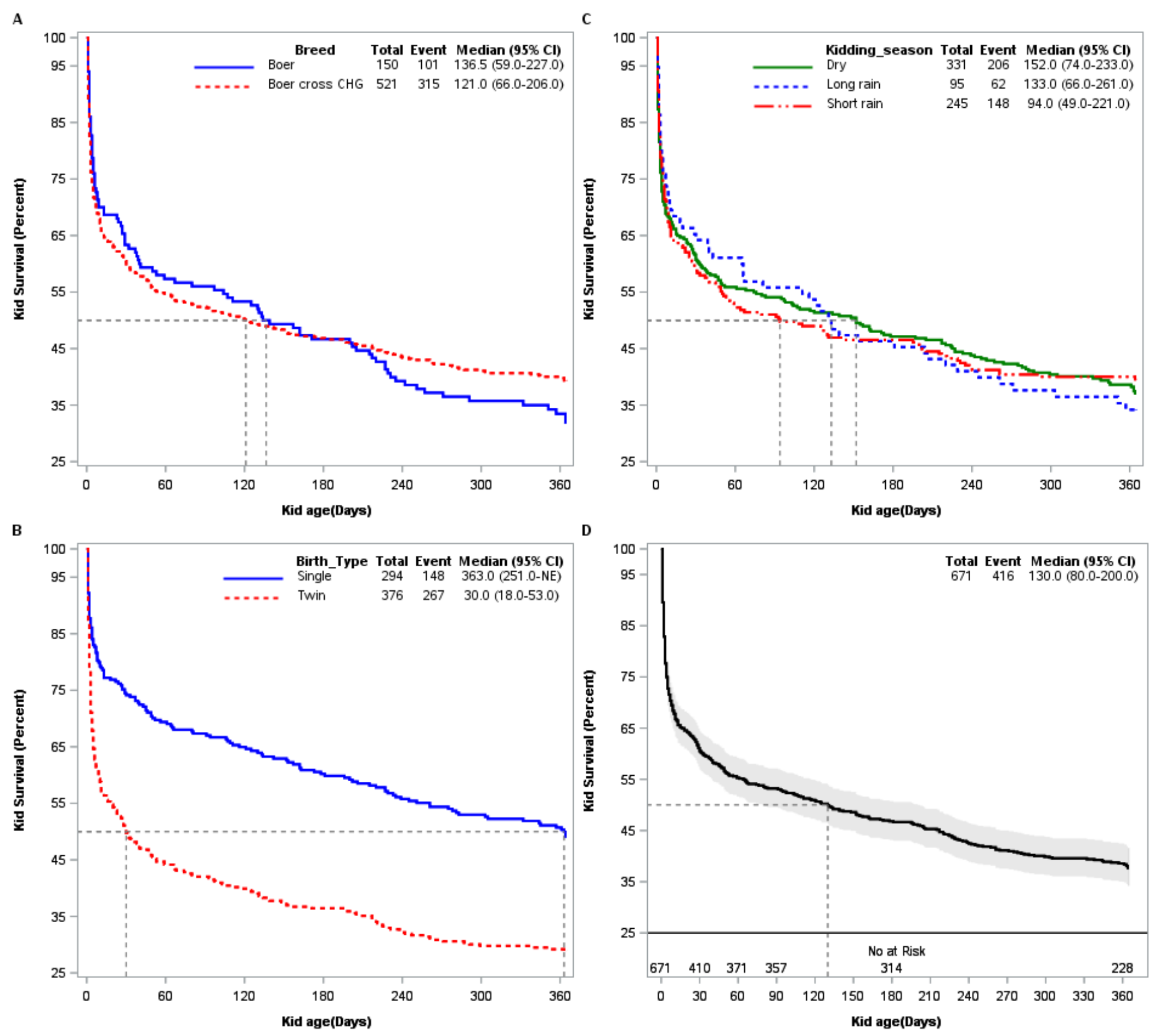

\section{Figure 2}

Kaplan - Maier survival function curve of kids (671) mortality and risk factors from birth to 1 year of follow-up period. 

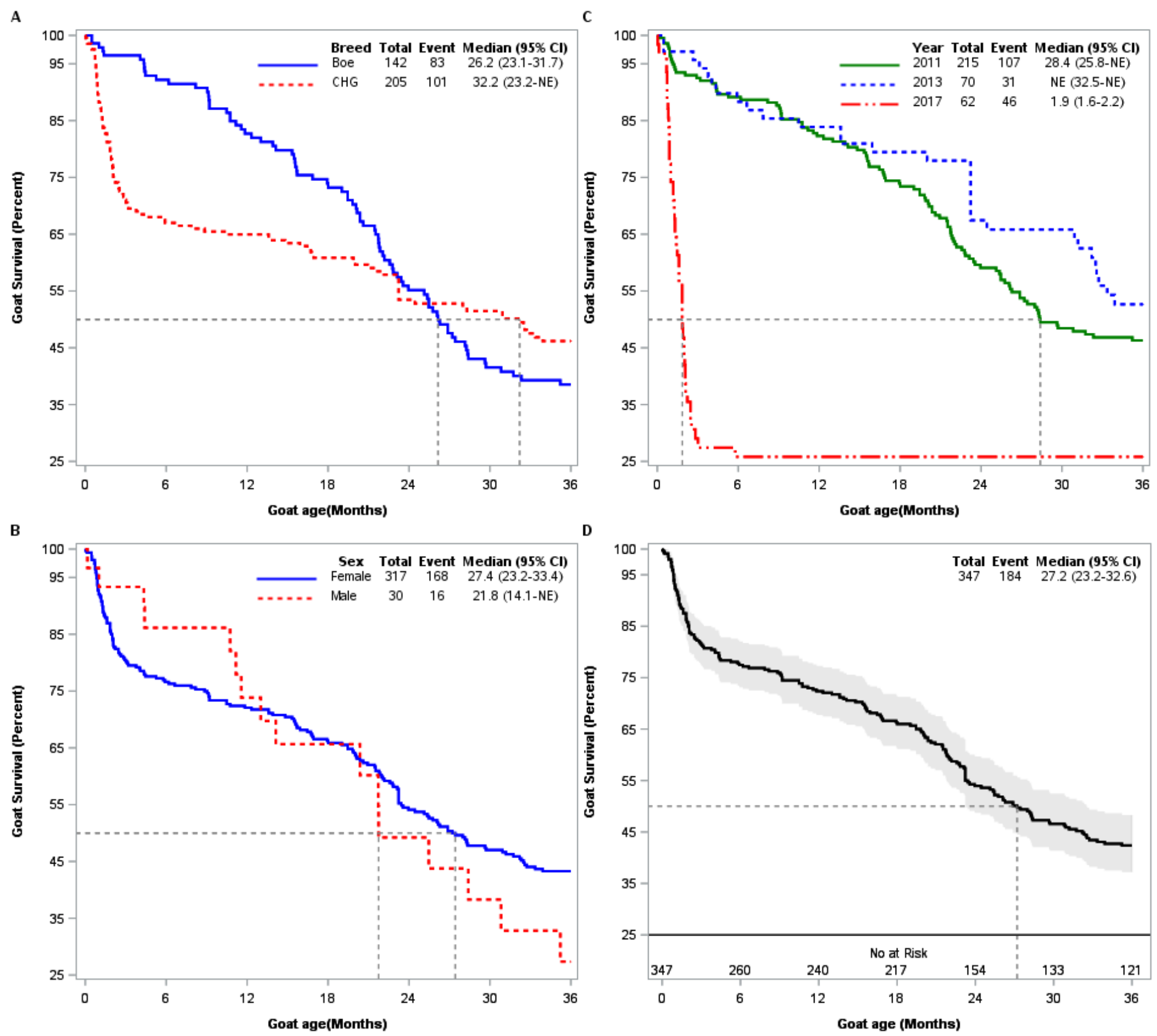

\section{Figure 3}

Kaplan - Maier survival function curve of yearling age goats (347) mortality and risk factors from entrance to farm to 3 year of follow-up period. 